\title{
Tobacco control in China: the dilemma
} between economic development and health improvement

\author{
Hong Wang, MD, PhD.(1)
}

\begin{abstract}
Wang $\mathrm{H}$.
Tobacco Control in China: the dilemma between economic development and health improvement. Salud Publica Mex 2006;48 suppl I:SI40-SI47.
\end{abstract}

\begin{abstract}
Although China's National People's Congress announced its decision to ratify the WHO's Framework Convention on Tobacco Control (FCTC) on Sunday, August 28, 2005, fundamental challenges to tobacco control still exist. A survey at the "No Smoking Day" on May 3I, 2004 in China showed that over $73 \%$ of respondents do not think that human society will be able to get rid of the consumption of tobacco products. Although the prevalence of smoking declined I.2\% from 1996 to 2002, the absolute number of smokers increased by 30 million during this period. It is estimated that smoking prevalence will decline $10 \%$ in the next 25 years. However, due to the population increase, the total number of tobacco consumers will be about the same as today, which is 320 million. As long as the tobacco industry continues to be significant in overall economic development, and as long as the government continues to play a significant role in tobacco production, the debate between tobacco production and tobacco control will continue. Although China has already made significant efforts with regard to tobacco control, it is still in the beginning of its "long march" towards improving the population's health status by reducing tobacco consumption in China.
\end{abstract}

Key words: tobacco; control; consumer; smoking; China

\section{Wang $\mathbf{H}$.}

Control del tabaco en China: el dilema

entre desarrollo económico y salud.

Salud Publica Mex 2006;48 supl I:SI40-S I47.

\section{Resumen}

A pesar de que el Congreso Nacional de la Población de China anunció su decisión de ratificar el Convenio Marco sobre Control de Tabaco (CMCT) el domingo 28 de agosto del 2005, los desafíos fundamentales a dicho control todavía existen. El análisis de "Un día sin tabaco", llevado a cabo el 31 de mayo del 2004 en China, demostró que alrededor de 73\% de los encuestados no piensan que la sociedad esté dispuesta a liberarse del consumo de los productos de tabaco. Aunque el predominio de fumadores disminuyó en $1.2 \%$ de 1996 al 2002, su número total se incrementó a 30 millones durante este periodo. Se estima que la prevalencia de fumadores disminuirá en un $10 \%$ en los próximos 25 años. Sin embargo, debido al aumento de la población, el total de consumidores de tabaco será próximo al actual, esto es, cerca de 320 millones. Mientras que la industria tabacalera siga siendo significativa en el desarrollo económico y los gobiernos aún jueguen un papel específico en la producción del tabaco, el debate entre la producción y el control de éste continuará. Aunque China ha hecho ya esfuerzos importantes en esta política de control todavía está al principio de su "largo camino" para mejorar el estado de la salud poblacional a partir de la reducción del consumo del tabaco en el país.

Palabras clave: tabaco; control; consumidor; tabaquismo; China
$\mathrm{T}$ obacco production and tobacco control policies have been debated intensively worldwide from various aspects. The centerpiece of these debates is economic development versus health improvement. From a health professional's perspective, tobacco consumption is seen as the major modifiable behavioral risk factor for many health problems including cancer, heart and respiratory diseases, and results in an enormous

(I) Yale School of Public Health. New Haven, Connecticut, USA. 
health care burden. ${ }^{1}$ From an economic development perspective, however, tobacco production is viewed as an important contributor to the economy, which includes the contributions to employment, incomes of people who work in tobacco production, and tax revenues. ${ }^{2}$ This debate becomes even more intensified in China due to the size of tobacco production as well as the magnitude of consumption and the role of the government in the health sector and tobacco industry.

\section{The tobacco industry and its contribution to economic development in China}

It is reported that China is the largest tobacco producer in the world; ${ }^{3}$ about one-third of tobacco products are produced in China. The tobacco industry includes three systems: tobacco agriculture, tobacco manufacturing, and the tobacco trade.

In the tobacco agricultural system, the land used for the growth of tobacco leaf and the yields of tobacco leaf was growing with a fluctuation in China during 1949 and 1997. In 1997 the amount of land used for growing tobacco reached 2.35 million hectares, and the yield of tobacco reached to 4.25 million tons (Table I). Although the land used for the growth of tobacco and the yield of tobacco has declined since 1997, about 1.26 million hectares of sown land was used for the grow-

Table I

TOTAL SOWN AREAS OF FARM CROPS AND TOBACCO yield IN China dURING 1978-2003

\begin{tabular}{|c|c|c|c|c|}
\hline Year & $\begin{array}{c}\text { Total } \\
\text { sown area } \\
\text { (I } 000 \text { Hectares })\end{array}$ & $\begin{array}{c}\text { Area for } \\
\text { tobacco } \\
\text { (I } 000 \text { Hectares) }\end{array}$ & $\begin{array}{c}\text { Percentage } \\
\text { of area } \\
\text { for tobacco (\%) }\end{array}$ & $\begin{array}{c}\text { Yield of } \\
\text { tobacco leaf } \\
\text { (10 000 Tons) }\end{array}$ \\
\hline 1978 & 150105.0 & 784.0 & 0.52 & 124.2 \\
\hline 1980 & 146381.0 & 512.0 & 0.35 & 84.5 \\
\hline 1985 & 143626.0 & 1313.0 & 0.91 & 242.5 \\
\hline 1989 & 146554.0 & I 798.0 & 1.23 & 283.0 \\
\hline 1990 & 148363.0 & I 593.0 & 1.07 & 262.7 \\
\hline |99| & 149586.0 & I 804.0 & 1.21 & 303.1 \\
\hline 1992 & 149008.0 & 2093.0 & 1.40 & 349.9 \\
\hline 1993 & 147741.0 & 2089.0 & 1.41 & 345.1 \\
\hline 1994 & $14824 \mid .0$ & I 490.0 & 1.01 & 223.8 \\
\hline 1995 & 149879.0 & I 470.0 & 0.98 & 231.4 \\
\hline 1996 & 152381.0 & I 853.0 & 1.22 & 323.4 \\
\hline 1997 & 153969.0 & 2353.0 & 1.53 & 425.1 \\
\hline 1998 & 155706.0 & 1361.0 & 0.87 & 236.4 \\
\hline 1999 & 156372.8 & I 373.7 & 0.88 & 246.9 \\
\hline 2000 & 156299.8 & I 437.2 & 0.92 & 255.2 \\
\hline 2001 & 155707.9 & 1339.6 & 0.86 & 235.0 \\
\hline 2002 & 154635.5 & I 327.6 & 0.86 & 244.7 \\
\hline 2003 & 152415.0 & I 264.4 & 0.83 & 225.7 \\
\hline
\end{tabular}

ing of tobacco in 2003, which was about $34 \%$ of the worldwide total of land used for the growing tobacco in the same year. Tobacco yield was 2.26 million tons, which was about $37.2 \%$ of overall worldwide production in 2003., 5

The areas where tobacco is grown include all provinces/municipal cities except Beijing, Shanghai, Tianjin, and Tibet (Table II). Yunnan, Guizhou, and Henan provinces are the first three provinces in terms of both the land used for growing tobacco and tobacco yield. Over $52 \%$ of tobacco was produced in these three provinces in $2003 .{ }^{4}$

Tobacco manufacturing is a state-run enterprise. The total number of cigarettes produced in China is about one-third of total production in the world. The annual increase in the total number of cigarettes produced was about $10 \%$ before 2000 (Table III). Although the annual increase has declined in recent years, the production of cigarettes reached 35.8 million boxes $(1$ box contains 50000 cigarettes) in 2003, which is 22 times as much as the production in $1949 .{ }^{5}$

The tobacco trade system includes both points of distribution and point of sale sub-systems. The point of distribution sub-system is a state-run system. During "The Ninth Five-Year Plan" period (1996 to 2000), about 4.2 billion yuan was invested in the tobacco distribution system, and 16530 points of distribution were built across the country. Among these points of distribution, 2640 are located in urban areas and 13890 are located in rural areas. ${ }^{5}$ In addition, there are nearly five million points of sale of cigarette across the country, most of which are owned by the private sector. ${ }^{6}$

Currently, the tobacco industry is a very important economic sector in China. It is reported that tobacco production significantly contributes to China's economy by providing both tax revenue to the government and employment to the population.

The revenue provided by the tobacco industry is one of the largest sources of government revenue. It is estimated that the contribution by the tobacco industry to the government revenue was 900 billion yuan between 1949 and 2000. Since the 1980s, tobacco tax revenue has been the number one source of revenue for the government. Tobacco tax revenue made up $11.2 \%$ of total government revenue in 1996. Although this figure has declined recently due to economic development in other sectors, tobacco taxes still made up about $7.4 \%$ of the government's total revenue in 2003 (Table IV). ${ }^{5}$ The tobacco industry is also one of the major sources of revenues to local governments in tobacco growing areas. It is estimated that over $70 \%$ of the tobacco leaf is produced in the midwest provinces, which are the least developed provinces in China. Tobacco production is very important in terms of economic 
Table II

TOtAl SOWN AREAS OF fARM CROPS AND tobacco YIELD by REgION, CHINA 2003

\begin{tabular}{|c|c|c|c|c|c|c|}
\hline Region & $\begin{array}{l}\text { Total sown area } \\
\text { (I } 000 \text { Hectares) }\end{array}$ & $\begin{array}{l}\text { Area for tobacco } \\
\text { (I } 000 \text { Hectares) }\end{array}$ & $\begin{array}{l}\text { Area for tobacco growth } \\
\text { in total sown area (\%) }\end{array}$ & $\begin{array}{l}\text { Yield of tobacco } \\
\text { (10 000 Tons) }\end{array}$ & $\begin{array}{l}\text { Tobacco growth area percentage } \\
\text { of total tobacco growth area (\%) }\end{array}$ & $\begin{array}{l}\text { Tobacco yield percentage } \\
\text { of total tobacco yield (\%) }\end{array}$ \\
\hline Beijing & 308.8 & 0.0 & 0.00 & 0.0 & 0.00 & 0.00 \\
\hline Tianjin & 501.5 & 0.0 & 0.00 & 0.0 & 0.00 & 0.00 \\
\hline Hebei & 8638.5 & 4.7 & 0.05 & I.I & 0.37 & 0.47 \\
\hline Shanxi & 3708.0 & 2.8 & 0.08 & 0.6 & 0.22 & 0.28 \\
\hline Inner Mongolia & 5752.8 & 6.6 & 0.11 & 1.6 & 0.52 & 0.70 \\
\hline Liaoning & 3719.1 & 13.7 & 0.37 & 2.6 & 1.08 & 1.17 \\
\hline Jilin & 4716.8 & 21.0 & 0.45 & 5.0 & 1.66 & 2.22 \\
\hline Heilongjiang & 9802.7 & 36.6 & 0.37 & 4.6 & 2.90 & 2.04 \\
\hline Shanghai & 419.2 & 0.0 & 0.00 & 0.0 & 0.00 & 0.00 \\
\hline Jiangsu & 7681.5 & 0.9 & 0.01 & 0.2 & 0.07 & 0.08 \\
\hline Zhejiang & 2834.4 & 2.2 & 0.08 & 0.5 & 0.17 & 0.22 \\
\hline Anhui & 9124.7 & 11.7 & 0.13 & 2.2 & 0.93 & 0.97 \\
\hline Fujian & 2518.9 & 59.6 & 2.37 & 10.3 & 4.71 & 4.56 \\
\hline Jiangxi & 4997.4 & 11.6 & 0.23 & 1.8 & 0.91 & 0.79 \\
\hline Shandong & 10885.3 & 42.9 & 0.39 & 9.6 & 3.39 & 4.24 \\
\hline Henan & 13684.4 & 134.0 & 0.98 & 21.8 & 10.59 & 9.64 \\
\hline Hubei & 7138.3 & 55.1 & 0.77 & 9.3 & 4.35 & 4.14 \\
\hline Hunan & 7731.2 & 94.1 & 1.22 & 18.7 & 7.44 & 8.29 \\
\hline Guangdong & 4883.4 & 29.9 & 0.61 & 6.0 & 2.37 & 2.66 \\
\hline Guangxi & 6279.1 & 16.1 & 0.26 & 2.6 & 1.27 & 1.17 \\
\hline Hainan & 906.7 & 0.1 & 0.01 & $\mathrm{~N} / \mathrm{A}$ & 0.01 & $\mathrm{~N} / \mathrm{A}$ \\
\hline Chongqing & 3365.8 & 57.2 & 1.70 & 8.6 & 4.53 & 3.81 \\
\hline Sichuan & 9384.5 & 66.6 & 0.71 & 13.4 & 5.27 & 5.95 \\
\hline Guizhou & 4634.2 & 207.2 & 4.47 & 31.2 & 16.39 & 13.80 \\
\hline Yunnan & 5756.0 & 343.7 & 5.97 & 65.5 & 27.18 & 29.01 \\
\hline Tibet & 233.7 & 0.0 & 0.00 & 0.0 & 0.00 & 0.00 \\
\hline Shaanxi & 4055.8 & 31.5 & 0.78 & 5.0 & 2.49 & 2.21 \\
\hline Gansu & 3620.9 & 13.4 & 0.37 & 3.1 & 1.06 & 1.38 \\
\hline Qinghai & 466.8 & 0.1 & 0.02 & 0.1 & 0.01 & 0.02 \\
\hline Ningxia & I 129.5 & 0.1 & 0.01 & 0.1 & 0.01 & 0.02 \\
\hline Xinjiang & 3535.0 & I.I & 0.03 & 0.3 & 0.09 & 0.15 \\
\hline Total & $1524 \mid 4.6$ & 1264.4 & 0.83 & 225.7 & 100.0 & 100.0 \\
\hline
\end{tabular}

Table III

Cigarettes manufactured in China FROM 1949 - 2003

\begin{tabular}{ccc} 
Year & Boxes $(10$ 000) & Annual increases (\%) \\
1949 & 160.0 & \\
\hline 1950 & 185.0 & 15.63 \\
\hline 1960 & 449.3 & 14.29 \\
\hline 1970 & 783.2 & 7.43 \\
\hline 1980 & 1520.0 & 9.41 \\
\hline 1990 & 3260.4 & 11.45 \\
\hline 2000 & 3336.3 & 0.23 \\
\hline 2001 & 3399.6 & 1.90 \\
\hline 2002 & 3444.9 & 1.33 \\
\hline 2003 & 3578.3 & 3.87
\end{tabular}

development in those regions. The contribution of the tobacco industry to government revenue in these provinces was 40 to $80 \%$ of overall government revenue. ${ }^{5}$

The contribution of the tobacco industry to employment includes tobacco farmers, people working in manufacturing, and staff members and salespersons in the tobacco trade system. In the agricultural sector, nearly 4.1 million rural households grow tobacco. They are located in 46000 villages and 4627 townships across the entire country. ${ }^{5}$ Approximately 215600 workers and staff members are employed in tobacco manufacturing. An additional 313800 people were employed by the tobacco trade system in $2003 .{ }^{5}$ Furthermore, there are nearly five million points of sale across the country which have provided job opportunities in the private sector. 


\section{Table IV}

THE CONTRIBUTION OF TOBACCO REVENUE to total government revenue, China

\begin{tabular}{|c|c|c|c|}
\hline Period/year & $\begin{array}{c}\text { Revenue } \\
\text { from tobacco }\end{array}$ & $\begin{array}{l}\text { Total } \\
\text { revenue }\end{array}$ & $\begin{array}{c}\text { Percentage of total } \\
\text { revenue (\%) }\end{array}$ \\
\hline "Ist 5-year plan" period & 4.3 & 135.5 & 3.20 \\
\hline "2nd 5-year plan" period & 4.1 & 211.7 & 1.95 \\
\hline $1963-1965$ & 2.9 & 121.5 & 2.40 \\
\hline "3rd 5-year plan" period & 5.9 & 252.9 & 2.35 \\
\hline "4th 5-year plan" period & 11.8 & 392.0 & 3.01 \\
\hline "5th 5-year plan" period & 20.0 & 496.1 & 4.04 \\
\hline "6th 5-year plan" period & 37.7 & 683.1 & 5.52 \\
\hline "7th 5-year plan" period & 106.5 & I 342.1 & 7.94 \\
\hline "8th 5-year plan" period & 226.1 & 2425.6 & 9.32 \\
\hline 1996 & 83.0 & 740.8 & 11.20 \\
\hline 1997 & 90.0 & 865.1 & 10.40 \\
\hline 1998 & 95.0 & 987.6 & 9.62 \\
\hline 1999 & 98.9 & I 144.4 & 8.64 \\
\hline 2000 & 105.0 & 1339.5 & 7.84 \\
\hline 2001 & 115.0 & 1638.6 & 7.02 \\
\hline 2002 & 140.0 & 1893.6 & 7.39 \\
\hline 2003 & 160.0 & 2168.1 & 7.38 \\
\hline
\end{tabular}

\section{Tobacco consumption and its potential effects on health and the economy}

China is not only the world's largest tobacco producer; it is also the world's largest tobacco consumer. Cigarettes produced in China are most often consumed in China. There are 360 million smokers in China, which accounts for nearly one-third of the world's smokers. ${ }^{7,8}$ According to China's Second National Survey of Smoking in 1996, the smoking rate was $37.6 \%$ for the total population. This rate was $66.9 \%$ for men and $4.2 \%$ for women. Compared to the results from the $1984 \mathrm{Na}-$ tional survey, smoking prevalence increased, the average number of smokers increased, and the average starting age decreased. ${ }^{9}$ A more recent study from the Chinese CDC reported that about $57 \%$ of males and $3 \%$ of females smoke, which is lower than the smoking rate from previous studies..$^{10}$ According to Chinese Statistical Bureau estimates, the quantity of tobacco consumption was 68.06 packs per person per year in 2002. The Chinese spend about $3 \%$ of per capita GDP on tobacco. -The average price of one pack of cigarettes is 3.71 yuan, and GDP per capita was 8214 yuan (\$1US= 8 Chinese Yuan). In addition to these active smokers, China also has 460 million passive smokers. ${ }^{11}$

It is well known that smoking can cause many deadly health problems, such as lung cancer and vas- cular disease, including heart attacks, strokes and other diseases of the arteries or veins, as well as chronic bronchitis and emphysema. Based on Peto-Lopez's methods, it is estimated that by 2010 about one million deaths in China will be due to cigarette smoking. ${ }^{12}$ This figure will increase to two million by 2025 and three million by 2050 . Half of these deaths will occur in people ages $35-69.10,13,14$

In addition to the health effects of smoking, smoking also has a major economic impact on smokers and their families. Although the Chinese Government obtained 105 billion yuan in revenue from tobacco taxes in 2000, the medical costs attributable to tobacco-related illness was about 48.6 billion yuan, or $46.3 \%$ of total tax revenue. ${ }^{5}$ In addition to these medical costs, smoking also reduces smokers' productivity. It is estimated that due to cardiovascular disease alone, Chinese people ages 35-64 lost 7.6 million years of productive life during the year 2000. ${ }^{15}$ A study from the Academy of Preventive Medicine reported that the tobacco revenue that government obtained from tobacco production was 24 billion yuan in 1989. In the same year, however, the total economic loss due to tobacco consumption was 28 billion yuan, which included 6.9 billion in costs due to medical services, 2.6 billion in costs due to loss of productivity, 17.6 billion in costs due to premature death, 0.9 billion in costs due to passive smoking, and 0.04 billion in costs due to fire accidents. ${ }^{16} \mathrm{~A}$ more recent study from Taiwan showed thatfinancial costs due to excess absenteeism, reduced productivity, and occupational injuries of employees who smoke were approximately US\$1 030 million: US\$184 million from increased sick leave, US\$81 million from environmental tobacco smoke, US\$34 million from occupational injuries, and US\$733 million from lost productivity. ${ }^{17}$

Tobacco consumption also reduces household consumption of other goods and services, which not only influences smokers themselves but also their family members. A recent study from the southwest China showed that rural households spend an average of $6.5 \%$ of their total expenditure on tobacco, which ranks as the $7^{\text {th }}$ highest expenditure amount. Due to financial constraints, these households have to make trade-offs between tobacco consumption and other types of consumption. The extreme households, those that have high-tobacco and high-alcohol consumption, allocate about $20 \%$ of their budget to tobacco and $11 \%$ to alcohol. Every 100 yuan spent on tobacco was associated with a 30 yuan decline in spending on education, a 15 yuan decline in spending on medical care, a 14 yuan decrease in spending on farming, and a 10 yuan decrease in spending on food. ${ }^{18} \mathrm{An}$ other study from China reports that poor urban households spend an average of $6.6 \%$ of their total ex- 
penditure on cigarettes and poor rural households spend $11.3 \%$ of their total expenditures on cigarettes. Reducing cigarette expenditures could release household resources for spending on food, housing, and other goods to improve the standard of living. ${ }^{19}$

\section{The role of government in tobacco production and the health sector}

The role of government in tobacco policies is a source of tension in China. On one hand, the Chinese government is responsible for improving the population's health. In order assure the Chinese population's health status, the Chinese government has invested heavily in the health sector, which includes owning and operating urban health insurance plans, subsidizing and operating the rural cooperative medical system (CMS), and owning and operating most health facilities that provide curative and preventive services to the population.

The Ministry of Health is the government agency that should take leadership of tobacco control. However, multi-sector participation is very important to the success of any tobacco control policy. The State Council approved "The notification of conducting health education on tobacco harm and tobacco control", which was established jointly, in 1979, by the Ministry of Health, Ministry of Finance, Ministry of Agriculture, and Ministry of Light Industry. Health education activities as a means of tobacco control have been implemented widely across the country ${ }^{16}$ Since 1990, the Association of Tobacco Control has been established at both the central and provincial level, and it has become the principal organization for public health education about tobacco. Their activities include non-smoking days, tobacco cessation, tobacco cessation hotlines and non-smoking schools, work places and public places.

A series of laws and regulations have included components related to tobacco control. These laws and regulations include the China Tobacco Monopoly Sales Law, Health Regulation in Public Places (1987), Child Protection Law (1991), Advertising Law (1994), and the Regulation Prohibiting Smoking in Public Transportation and Waiting Places (1997). ${ }^{6}$ In addition, on August 28, 2005, China's National People's Congress announced its decision to ratify the WHO's Framework Convention on Tobacco Control (FCTC). This is a significant step towards improving the population's health by reducing tobacco consumption in China.

On the other hand, the Chinese government is responsible for economic development. As described previously, the tobacco industry provides substantial revenues to the government. In order to ensure this revenue, the Chinese government plays a monopolis- tic role in tobacco production. The China National Tobacco Company (CNTC), a monopoly under the State Tobacco Monopoly Administration (STMA), controls all tobacco growth, cigarette manufacturing, and the cigarette market. In addition, the tobacco industry provides significant job opportunities to the Chinese population, especially in many relatively poor regions.

Obviously, the Chinese government plays mixed roles in terms of tobacco control and tobacco production. On one hand, the Chinese government made significant efforts to discourage cigarette consumption through public campaigns. On the other hand, the Chinese government itself runs the largest tobacco enterprise in the world. The health-related sectors of the government have not been able to convince the other economic sectors to support some of their tobacco control policies. As one government official in the tobacco production sector said, tobacco production is not only related to the health of the population, it is also related to economic development, employment, agricultural economic structure, the standard of living, and social stability. ${ }^{20}$ The conflict of interests among policy makers between public health and economic development constitutes a major dilemma within the Chinese government.

\section{The continuum of the debate on tobacco control policies}

\section{Raising the tobacco tax}

One of the major debates is with regard to raising cigarette taxes. Worldwide evidence has showed that raising tobacco taxes does significantly reduce the consumption of tobacco. The price effect on tobacco consumption is likely to be greatest on young people and more significant in low- and middle-income countries. ${ }^{21}$ In addition to the huge health benefits gained, raising the tobacco tax will not harm government revenues or economic development. ${ }^{22}$ A comprehensive Chinese study showed that the price elasticity of demand for cigarettes is -0.54 in China. By introducing an additional $10 \%$ increase in cigarette tax per pack, the government's increase in tax revenue would exceed two-fold the total losses in industry revenue, tobacco farmers' income, and local tax revenue. In addition, between 1.4 and 2.2 million lives would be saved by such a tax increase. ${ }^{23}$

However, government officials in the tobacco production sector disagree with the above conclusions. They expressed the view that if the price of cigarettes increased people may simply switch to cheaper cigarettes, which have more tar and nicotine and thus are 
even more harmful to people's health. They are also concerned that after a price increase, smuggling would increase and would be difficult to control, which not only influences the economy, but would also keep the government from controlling the tar and nicotine levels in cigarettes. Certainly, the biggest concern for them is the economic impact. If tobacco consumption declines, government revenue from tobacco production will be reduced; the tobacco manufacturers may go bankrupt; and people who work in the tobacco industry may become unemployed. ${ }^{5}$

\section{Introducing low harm tobacco products}

In order to carry out their responsibility for improving population health, one of the major strategies proposed by the tobacco production sector is to introduce lower harm tobacco products, which would reduce the health damage due to tobacco consumption, but also maintain the contribution of the tobacco industry to the economy. Since 1984, tobacco products have been classified into three levels, low-tar $(<15 \mathrm{mg} /$ per cigarette), moderate-tar (15-25mg/per cigarette), and high-tar (>25mg/per cigarette). In order to encourage the tobacco industry to produce low-tar products, new criteria have been recently introduced. This new criteria classifies cigarettes into five levels, low-tar $(<=12 \mathrm{mg} /$ per cigarette), low-moderate-tar $(12-16 \mathrm{mg} /$ per cigarette), moderate-tar (16-19mg/per cigarette), moderate-high-tar (19-23mg/per cigarette), and high-tar $\left(>=23 \mathrm{mg} /\right.$ per cigarette)..$^{5}$ In 2000 , the STMA proposed a reduction in tar levels by $0.5 \mathrm{mg} /$ per cigarette per year. The average tar level has declined from $16.5 \mathrm{mg} /$ per cigarette in 1999 to $13.5 \mathrm{mg} /$ per cigarette in $2004 .{ }^{6}$ However, the "low-tar low harm" has not been supported by evidence, ${ }^{21}$ and the approach of introducing low-tar tobacco products has not been accepted by the health-related governmental sectors.

In addition to introducing low-tar cigarettes, some tobacco manufacturers have added traditional Chinese medicines to their tobacco products in order to "improve" the consumer's health. Traditional medicines were added that can improve lung function and kidney function. A report of "The New Life of a Sunset Industry" described how a Nanchang tobacco manufacturer, a 40 year-old enterprise, introduced a new brand, Jinsheng, to the market in the early 90 's. This brand passed tests conducted by the National Tobacco Bureau and Chinese Medicine Expert Panel in 1994 and won the national innovation award in 1995. The company began with the production of 2000 boxes in 1992, and increased to 100000 boxes in $1999 .{ }^{24}$ Many other tobacco manufacturers have also produced cigarettes that include Chinese medicines. However, there are no existing regulations to control such products, which could have even more negative impact on smokers' health status. In addition, these brands provide a twisted message to the consumer, which may induce tobacco consumption and reduce the willingness to quit. ${ }^{6}$

\section{Consumer information}

Although health education on tobacco use has been implemented widely across the whole country since the State Council approved, in 1979, "The Notification of Conducting Health Education on Tobacco Harm and Tobacco Control" -which was established jointly by the Ministry of Health, Ministry of Financing, Ministry of Agriculture, and Ministry of Light Industry- the effects on tobacco consumption reduction have been quite limited. ${ }^{16}$ The Tobacco Consumption Survey in 1996 demonstrated that $60 \%$ of smoker considered tobacco's effects on health to be "very limited or no harm." How to deliver tobacco control information more effectively is one of the challenges for reducing tobacco consumption.

By 1991, seventy-seven countries, including China, had introduced warning labels on tobacco products to warn the consumer that tobacco is harmful to their health. However, the warning label on tobacco products is very small, and sometimes is only on the side of the package. The World Health Organization (WHO) recommends that the warning should be specific, such as "tobacco can cause cancer," or "tobacco will induce a heart attack," and that the label should be large and on the front side of the package. This recommendation, however, will be very difficult to adopt in China in the near future. People in the tobacco industry explain that many cigarettes are purchased as gifts and if the warning label is one-third the size of the front of the package, nobody will purchase such products. ${ }^{25}$

In order to market tobacco products, tobacco manufacturers not only try to avoid putting warning labels in a notable place on their product, but also try to link their products with images that can make them seem as a good and responsible player in the society. For example, the Beijing Cigarette Manufacturing Company links their tobacco product, "Zhong Nan Hai," with the Hope Project. The Hope Project is a project that provides funds to support poor children who cannot afford the tuition to finish school. The tobacco company puts the label "your consumption will support the Hope Project" on the package. The company intends to use Hope Project to promote its tobacco products. ${ }^{25}$

Although the Advertising Law prohibits having tobacco related advertisements in movies, television, newspapers and journals, many images related to tobacco 
consumption still exist in the media. A study conducted by the MOH showed that in the most popular 10 movies between 2001-2002, all have images of tobacco consumption. The average number of episodes of tobacco consumption per movie was 26.2. The maximum number of episodes of tobacco consumption in one movie was 111. The average length of a movie segment that included tobacco consumption image was 5.6 minute. The longest length of a segment that included tobacco consumption was 15 minutes. Although these tobacco consumption pictures are not produced by the tobacco industry, the effects of those pictures on people's smoking behavior is significant, especially for youth. ${ }^{26}$

\section{International tobacco penetration}

Aside from many debates, both tobacco control and tobacco production sectors in China are facing a new challenge, foreign tobacco's penetration into the Chinese tobacco market after China joined WTO. ${ }^{27}$

Morgan Stanley published their report "China: the final frontier" on July $26,2005 .^{28}$ This report provided an in-depth analysis of the current status of China's tobacco industry, consumer preferences, government roles, and the activities of foreign tobacco companies in China. This report pointed out that many investors fear that the world tobacco market would shrink inexorably and even disappear. To avoid this disaster, the report suggested that these investors should go to China. By entering the Chinese tobacco market, they "could increase the size of the available world market by 40 to $50 \% . "$

Although there is a huge market for tobacco in China, the share of foreign tobacco is very small: less than $3 \%$ of the total market. However, as China begins to implement the WTO commitment it made on January 1,2004, the tobacco import tax will decline and foreign cigarettes will be able to be produced locally, thus avoiding import taxes and making foreign brands more available to Chinese consumers. Due to the tax decrease and supply increase, the price of foreign tobacco products may decline, which could lead to an increase in the consumption of foreign tobacco. If the price of foreign brand tobacco products declines, the price of domestic brands may also decline due to market competition, and total consumption may therefore increase.

In the face of penetration by foreign tobacco in China, the Chinese tobacco industry has had to increase its ability to compete with the international tobacco industry in the country. ${ }^{20,27}$ They have also used international penetration as an excuse to fight tobacco control efforts. One former government official who works in the tobacco production sector complains that tobacco control efforts reduced the innovative and competitive capacity of the tobacco industry, which is harmful to China's economic development and harmful to the Chinese people. ${ }^{20}$ The tobacco control sector in China has to confront challenges from both international and domestic tobacco industries.

\section{Conclusion}

In conclusion, although China's National People's Congress announced its decision to ratify the WHO's Framework Convention on Tobacco Control (FCTC) on August 28, 2005, fundamental challenges to tobacco control still exist. A survey at the "No Smoking Day" in China on May 31, 2004 showed that over 73\% of respondents do not think that the society will be able to eliminate the consumption of tobacco products. ${ }^{25}$ Although the prevalence of smoking declined 1.2\% from 1996 to 2002, the absolute number of smokers increased by 30 million during this period. ${ }^{6}$ It is estimated that smoking prevalence will decline $10 \%$ in the next 25 years. However, due to the population increase, the total number of tobacco consumers will be about the same as today, which is 320 million. ${ }^{26}$ As long as the tobacco industry continues to be significant in overall economic development, and as long as the government continues to play a significant role in tobacco production, the debate between tobacco production and tobacco control will continue. Although China has already made significant efforts towards tobacco control, it is still at the beginning of its "long march" towards improving the population's health by reducing tobacco consumption in China.

\section{References}

I. McQueen DV, Mckenna MT, et al. Chronic diseases and injury. In: Merson MH, Black RE, Mills AJ, ed. International Public Health: Diseases, Programs, Systems and Policies. Gaithersburg, Maryland:Aspen Publications; 2002:293-330.

2. Chaloupka FJ,Warner KE. The economics of smoking. In: Culyer AJ, Newhouse JP, ed. Handbook of health economics. Vol. IB. New York: Elsevier; 2000:I539-1627.

3.World Health Organization. Tobacco or health: A global status report. Geneva:WHO, 1997.

4. China Statistics Bureau. 2003 China statistics yearbook. Beijing: China Statistics Bureau, 2004.

5. Liu T, Xiong B. Tobacco economy and tobacco control. Beijing: Economic Science Press, 2004.

6. Zheng F, Zhao B, et al. Report on China tobacco industry and the implication of FCTC. Journal of Academy of Tobacco Science 2005; I I suppl I:32-36.

7. Lam, TH, He Y, et al. Mortality attributable to cigarette smoking in China. JAMA 1997; 278 suppl I8:I505-I508.

8. People's Daily. China faces hard job to control smoking. China: People's Daily, 2000. 
9. Yang, GH. 1996 National prevenlance survey of smoking patterns. Beijing: China Science and Technology Press, 1997.

10. Yang G, Ma J, et al. Smoking and passive smoking in Chinese. China Journal of Epidemiology 2005;26:78-83.

I I. Zhu J.To coordinate the conflict between tobacco control and tobacco production in China. Periscope 1996;46:12-13.

12. Peto R, Lopez A, et al. Mortality from smoking in developed countries, 1950-2000. Oxford: Oxford University Press, 1994.

13. Niu S, Yang G, et al. Emerging tobacco hazards in China: Early mortality results from a prospective study. BMJ 1998;317 suppl 2I:1423-I424.

14. World Health Organization. The World Health Report 1999: Making a difference. Geneva:WHO, 1999.

15.Wang L, Kong L, et al. Preventing Chronic Disease in China. Lancet 2005: I82 I-1824. Available in: www.thelancet.com.

16. Yuan X.The discussion on tobacco economy and health economy. Medicine and Philosophy 1994;suppl I:8-10.

17.Tsai, SP,Wen CP, et al.Workplace smoking related absenteeism and productivity cost in Taiwan. Tob Control 2006; I4 suppl I:i33-i37.

I8. Wang H, Sindelar J, et al. The impact of tobacco expenditure on household consumption patterns in rural China. Soc Sci Med 2006;62:14|4-I426.
19. Hu TW, Mao Z, et al. Smoking, standard of living, and poverty in China. Tob Control 2005; 14:247-250.

20. Ma Z. "FCTC" and its impact on tobacco production in China. China Economic Weekly 2005;319 suppl 36:36-37.

21. The World Bank. Curbing the epidemic: Governments and the economics of tobacco control. Washington DC:The World Bank, 1998. 22. Jha P, Beyer J, et al. Death and taxes: Economics of tobacco control. Finance Dev 1999; 12:46-49.

23. Hu TW, Mao Z. Effects of cigarette tax on cigarette consumption and the Chinese economy. Tob Control 2002; I : 105-108.

24. Zhou B, Zheng J. New life of a sunset industry. Feng Yun Ren Wu 1997; 10:26-28.

25. Zhang T.Why is it so difficult to control tobacco in China? Science World 2005;8:37-38.

26. Wei, Y.The World FCTC and its impact on the tobacco industry in China. China Foreign Investment 2005;5:36-39.

27. Yang ZY.The WTO and its impact on China's tobacco economy Reform and Its Theory 2000; I I 3 suppl 5:5I-53.

28. Fell J, Khoo E, et al. China:The final frontier. Morgan Stanley [report], July 26, 2005. 